\title{
Pengaruh Model Kooperatif Tipe Cooperative Integreted Reading and Composition terhadap Kemampuan Pemecahan Masalah Matematika Siswa Kelas VIII SMP Negeri 2 Bengkalis
}

\author{
Muhammad Fahmi ", Mas`ud Zein** \\ * Universitas Islam Negeri Sultan Syarif Kasim Riau, Pekanbaru \\ m.fahmi@gmail.com \\ ** Universitas Islam Negeri Sultan Syarif Kasim Riau, Pekanbaru \\ masud.zein@uin-suska.ac.id
}

\section{INFO ARTIKEL}

\section{Riwayat Artikel:}

Diterima: 12 Oktober 2018

Disetujui: 25 Juni 2019

\section{Kata kunci:}

Pembelajaran Kooperatif

Cooperative Integreted Reading and Composition

Kemampuan Pemecahan Masalah

\section{Alamat Korespondensi:}

\section{ABSTRAK}

\begin{abstract}
This article aim to to know there is or do not it him difference of ability of troubleshooting between class using type cooperative model of Cooperative Integreted Reading Composition and at class student of VIII SMP Country 2 Bengkalis District of Bengkalis SubProvince of Bengkalis, and difference oflis make-up of ability of trouble-shooting. This research represent research of experiment kuasi with people of sampel this research is class of VIII.B amounting to 23 people as experiment class and class of VIII.C amounting to 23 people as control class. Pursuant to result of analysis can be taken by conclusion that there are difference of ability of trouble-shooting of student mathematics between using type cooperative model of CIRC and conventional study. This seen from complete mean of result learn with type cooperative model of $\mathrm{CIRC}$ equal to 83,30 is better the than result learn with conventional study equal to 73,96, and difference of improvement can be seen from test of tes $N$-Gain $t$ that is equal to 4,07. There by can be concluded that there are influence which are positive when using type cooperative model of CIRC to ability of trouble-shooting of student of SMP Country 2 Bengkalis..
\end{abstract}

\begin{abstract}
Abstrak: Artikel ini bertujuan untuk mengetahui ada atau tidaknya perbedaan kemampuan pemecahan masalah antara kelas yang menggunakan model kooperatif tipe Cooperative Integreted Reading and Composition pada siswa kelas VIII SMP Negeri 2 Bengkalis Kecamatan Bengkalis Kabupaten Bengkalis, dan perbedaan peningkatan kemampuan pemecahan masalah. Artikel ini merupakan penelitian kuasi eksperimen dengan sampel penelitian ini adalah kelas VIII.B yang berjumlah 23 orang (sebagai kelas eksperimen) dan kelas VIII.C yang berjumlah 23 orang (sebagai kelas kontrol). Berdasarkan hasil analisis dapat diambil kesimpulan bahwa terdapat perbedaan kemampuan pemecahan masalah matematika siswa antara yang menggunakan model kooperatif tipe CIRC dan pembelajaran konvensional. Ini terlihat dari mean ketuntasan hasil belajar dengan model kooperatif tipe CIRC sebesar 83,30 lebih baik dari hasil belajar dengan pembelajaran konvensional sebesar 73,96, dan perbedaan peningkatan dapat dilihat dari uji tes $t \mathrm{~N}$-gain yaitu sebesar 4,07. Dengan demikian, dapat disimpulkan bahwa terdapat pengaruh yang positif bila menggunakan model kooperatif tipe CIRC terhadap kemampuan pemecahan masalah siswa SMP Negeri 2 Bengkalis.
\end{abstract}

Mas`ud Zein,

Universitas Islam Negeri Sultan Syarif Kasim Riau, Pekanbaru

Email: masud.zein@uin-suska.ac.id

\section{LATAR BELAKANG}

Indikasi pemecahan masalah dalam pembelajaran matematika adalah agar siswa mampu memecahkan masalah yang dihadapi dalam kehidupannya, sehingga matematika merupakan salah salah satu ilmu yang penting untuk dipelajari baik dari tingkat dasar hingga perguruan tinggi. Pentingnya pembelajaran matematika dalam memecahkan masalah juga dikemukakan oleh Cornellius sebagaimana dikutip dalam Abdurrahman (2003), yaitu: 1) matematika 
sebagai sarana berpikir jelas dan logis; 2) matematika sebagai sarana mengenali pola-pola hubungan dan generalisasi pengalaman; 3) matematika sebagai sarana untuk memecahkan masalah kehidupan nyata; 4) matematika sebagai sarana untuk mengembangkan kreatifitas; dan 5) matematika sebagai sarana untuk mengembangkan kesadaran terhadap perkembangan budaya. Dengan mempelajari matematika siswa selalu dihadapkan kepada masalah matematika yang terstruktur, sistematis dan logis yang dapat membiasakan siswa untuk mengatasi masalah yang timbul secara mandiri dalam kehidupannya tanpa harus selalu meminta bantuan kepada orang lain. Kemampuan pemecahan masalah matematika pada siswa dapat diketahui melalui soal-soal yang berbentuk uraian atau cerita, karena pada soal yang berbentuk uraian atau cerita kita dapat melihat langkah-langkah yang dilakukan siswa dalam menyelesaikan suatu permasalahan, sehingga pemahaman siswa dalam pemecahan masalah dapat terukur. Bentuk soal pemecahan masalah yang difokuskan pada penelitian ini adalah soal cerita, berdasarkan buku-buku penunjang pelajaran matematika yang mengacu pada kurikulum, banyak dijumpai soal-soal yang berbentuk soal cerita hampir pada setiap materi pokok. Menyelesaikan soal matematika bukan hanya untuk menerapkan matematika saja tetapi untuk belajar matematika yang baru, maksudnya saat siswa melibatkan diri dalam tugas-tugas berbasis soal yang dipilih dengan baik dan memfokuskan pada metode-metode penyelesaian, maka apa yang akan terjadi adalah pemahaman baru tentang matematika yang tersisipkan di dalam tugas tersebut. Seperti yang dikutip John A. Van De Wallec (2006) dalam bukunya Elementary and Middle Shool Mathematics, menyatakan:

Penyelesaian soal matematika bukan hanya sebagai tujuan dari belajar matematika, tetapi juga merupakan alat utama untuk belajar matematika...penyelesaian soal merupakan bagian yang tidak terpisahkan dari semua proses belajar matematika, sehingga seharusnya tidak dijadikan sebagai bagian yang terpisah dari program pengajaran matematika. penyelesaian soal dalam matematika harus mencakup kelima wilayah materi yang digambarkan di dalam standar ini...soal-soal yang baik akan menggabungkan beberapa topik dan meliputi matematika yang penting. (NCTM).

Namun kenyataannya, banyak siswa yang mengalami kesulitan belajar matematika. Kesulitan-kesulitan yang dihadapi siswa dalam belajar matematika, kesulitan dalam bahasa dan membaca juga berperan penting dalam mempelajari matematika. Seperti yang dinyatakan Lerner dalam Abdurrahman (2003) ada beberapa karakteristik anak berkesulitan belajar matematika, yaitu: adanya gangguan dalam hubungan keruangan, kesulitan mengenal dan memahami simbol, kesulitan dalam bahasa dan membaca. Soal matematika yang berbentuk cerita menuntut kemampuan bahasa dan membaca yang tinggi untuk memecahkan masalah matematika. Kenyataanya dari hasil observasi siswa kelas VIII SMP Negeri 2 Bengkalis memperlihatkan bahwa mereka kesulitan dalam memecahkan persoalan matematika yang diberikan khususnya dalam memecahkan masalah soal cerita, ini bisa dilihat mereka sulit dalam mengidentifikasi masalah, memahami makna dari soal, menemukan dengan tepat apa arti masalah, selain itu mereka juga sulit dalam merubah soal cerita yang ada kedalam model matematika. Hal ini salah satu penyebabnya dikarenakan siswa kurang pemahaman dalam membaca atau pemahaman linguistik serta menulis, yang berarti bahwa murid perlu memahami seluruh arti kalimat yang terdapat di dalam soal serta menulis dalam kalimat matematika. Walaupun membaca dan menulis pada matematika berbeda dengan membaca dan menulis secara umum namun ia sangat berperan penting dalam menyelesaikan permasalahan matematika. Kita ketahui membaca soal matematika tidak hanya membaca secara harfiah saja namun membutuhkan cara berpikir logis. Akan tetapi pada kenyataannya di sekolah, membaca hanya lebih menekankan pada kalimat harfiahnya saja tanpa memahami makna yang sebenarnya, menganalisis makna yang terkandung dalam kalimat yang dibaca tersebut. Seperti yang dinyatakan Guszak dalam penelitiannya pada tingkat sekolah dasar, Guszak menyatakan: "adanya penekanan yang berlebihan pada kemampuan memahami bacaan secara harfiah daripada kemampuan memahami bacaan secara secara interpretif dan logis" dari pernyetaan Guszak ini dapat juga kita tangkap kurangnya kemampuan membaca inilah yang menyebakan kurangnya kemampuan siswa dalam memecahkan masalah matematika yang berbentuk soal cerita yang memerlukan analisis dalam membacanya (E Slavin, 2005).

Selain itu, proses pembelajaran yang dilakukan guru matematika SMP Negeri 2 Bengkalis yaitu mengajarkan atau menerangkan materi kemudian dilanjutkan dengan pemberian contoh soal, dan selanjutnya diakhiri dengan memberikan pekerjaan rumah atau PR. Guru juga mendorong siswa untuk bertanya jika ada materi yang belum mereka pahami. Pembelajaran tersebut kurang efektif karena pembelajaran tersebut masih bertumpu kepada guru sehingga siswa kurang aktif dan siswa cepat lupa terhadap pelajaran tersebut disebabkan siswa hanya menerima saja bukan menemukan dan memecah masalah matematika tersebut. Sehingga ada sebagian siswa yang memperoleh hasil belajar di bawah KKM, ini berarti menggambarkan kemampuan pemecahan masalah matematika siswa masih rendah.

Dari permasalahan di atas, maka peneliti perlu mencari metode atau model yang tepat, agar tujuan dari pembelajaran itu tercapai. Menurut Suryadi dalam penelitiannya pada pelajaran matematika menyimpulkan bahwa "salah satu model pembelajaran yang efektif untuk meningkatkan kemampuan berpikir siswa adalah pembelajaran aktif (Isjoni, 2009).” Salah satu model pembelajaran yang efektif adalah pembelajaran kooperatif. Ada banyak model pembelajaran kooperatif dalam pembelajaran matematika yang memenuhi ciri pembelajaran efektif diantaranya model kooperatif tipe CIRC (Cooperative Integrated Reading and Composition). CIRC merupakan program komprehensif untuk mengajarkan membaca dan menulis pada tingkat yang lebih tinggi. Menurut Palinscar dan 
Brown dalam E.Slavin (2005) bahwa "para siswa dalam CIRC juga membuat penjelasan terhadap prediksi mengenai bagaimana masalah-masalah akan diatasi dan merangkum unsur-unsur utama dari cerita kepada satu sama lain, yang ditemukan dapat meningkatkan pemahaman dalam membaca”. Seperti yang diketahui dalam memecahkan masalah matematika memerlukan pemahaman membaca dan menulis yang tinggi apalagi berkaitan dengan bentuk soal cerita, sehingga dengan model pembelajaran CIRC siswa mampu dan terampil menyelesaikan masalah dalam soal cerita dengan langkah-langkah yang tepat.

\section{METODE}

Desain yang digunakan dalam penelitian ini adalah Pretest-Posttest Conttrol Group Design (Setyosari, 2010). Terdapat dua kelompok yaitu kelompok eksperimen yang akan memperoleh pengajaran dengan model pembelajaran kooperatif tipe CIRC dan kelompok kontrol yang mendapat pengajaran konvensional. Dua kelompok tersebut diberikan pretes dan postes. Pretes diberikan untuk mengetahui keadaan awal terhadap materi adakah perbedaan antara kelompok eksperimen dan kelompok kontrol. Hasil pretes yang baik bila nilai kelompok eksperimen tidak berbeda secara signifikan. Populasi dalam penelitian ini adalah seluruh siswa kelas VIII yang berjumlah 5 kelas semester ganjil SMP Negeri 2 Bengkalis, tahun ajaran 2012 sebanyak 114 peserta didik. Sampel diambil dari dua kelas yang ditentukan oleh peneliti yang sudah diuji tingkat homogenitas, normalitas, dan tingkat perbedaan kemampuan siswanya untuk lebih jelas bisa dilihat pada lampiran K. Di mana kelas VIII B sebagai kelas eksperimen yang akan digunakan strategi Pembelajaran dan kelas VIII C sebagai kelas kontrol dengan model pembelajaran konvensional. Metode atau teknik pengumpulan data ialah teknik atau cara-cara yang digunakan untuk mengumpulkan data. Metode atau teknik menunjukkan suatu kata yang abstrak dan tidak diwujudkan dalam benda, tetapi hanya dapat dilihatkan penggunaannya melalui: angket, wawancara, pengamatan, ujian (tes), dokumentasi, dan lainnya. Teknik analisis data yang akan dilakukan pada penelitian ini adalah tes"t" dan analisis deskriptif untuk lembar observasi. Tes " $\mathrm{t}$ " adalah salah satu uji statistik yang digunakan untuk mengetahui ada atau tidaknya perbedaan yang signifikan (meyakinkan) dari dua buah mean sampel (dua buah variabel yang dikomparatifkan) (Hartono, 2008).

\section{HASIL}

Kemampuan pemecahan masalah dianalisis melalui data hasil pretes dan postes di akhir pemberian tindakan. Namun, sebelumnya data tersebut diujikan untuk mengetahui homogen dan normal data yang kemudian dilanjutkan dengan tes $t$, analisis data untuk mengetahui adanya perbedaan kemampuan pemecahan masalah antara kelas menggunakan pembelajaran model kooperatif tipe CIRC dengan kelas konvensional. Adapun pada bagian ini akan dibahas mengenai kemampuan awal, kemampuan akhir dan peningkatan hasil belajar siswa.

\section{Kemampuan Awal}

Pengujian homogenitas yang peneliti lakukan adalah dari hasil nilai pretest siswa kelas VIII yang terdiri dari 5 kelas. Uji homogenitas ini dilakukan dengan uji Bartlett ternyata setelah dilakukan pengujian, 5 kelas ini terbukti homogen untuk lebih lengkap dapat dilihat pada lampiran K. Karena ke 5 kelas tersebut homogen maka peneliti mengambil 2 kelas secara acak yang akan dijadikan kelas eksperimen dan kelas kontrol dan juga telah diuji kehomogenitasnya dengan. Adapun yang menjadi kelas eksperimen adalah kelas VIII B dan kelas VIIIC sebagai kelas kontrol. Berikut ini ditampilkan hasil dari uji homogenitas, sebagai berikut:

Tabel 1. Hasil Uji Homogenitas Pretes

\begin{tabular}{ccc}
\hline Nilai Varian Sampel & Kelas VIII B & Kelas VIII C \\
\hline$S^{2}$ & 543,08 & 652,08 \\
$N$ & 23 & 23 \\
\hline
\end{tabular}

Ternyata $F_{\text {hitung }}<F_{\text {tabel }}$ atau $1,2<2,03$, maka varians-varians adalah homogen. Kemampuan awal siswa dilihat berdasarkan skor pretes dari kedua kelas penelitian yaitu kelas VIII B dan kelas VIII C. Selanjutnya skor pretes diolah dengan menggunakan uji Lilifors. Hasil pengujian normalitas bagi skor pretes untuk kelas VIII B dan kelas VIII C Selengkapnya dapat dilihat pada hasil rangkuman pada Tabel 2 berikut.

Tabel 2. Uji Normalitas Pretes

\begin{tabular}{cccc}
\hline Kelas & $L_{\text {hitung }}$ & $L_{\text {tabel }}$ & Kriteria \\
\hline VIII B & 0,1515 & 0,1730 & Normal \\
VIII C & 0,1423 & 0,1730 & Normal \\
\hline
\end{tabular}

Berdasarkan hasil penelitian, dapat diamati bahwa nilai $L_{\text {hitung }}$ kelas VIII B sebesar 0,1515 sedangkan untuk nilai $L_{\text {hitung }}$ kelas VIII C sebesar 0,1423. Harga $L_{\text {tabel }}$ dalam taraf signifikansi 5\% untuk kelas VIII B adalah 0,1730 dan kelas VIII C 0.1730. Dengan demikian, $L_{\text {hitung }}<L_{\text {tabel }}$ maka dapat dikatakan bahwa data berasal dari populasi yang berdistribusi normal. Karena telah memenuhi kedua syarat tersebut, kemudian dilanjutkan analisis data dengan tes 
"t" dapat menggunakan uji statistik Compare Mare Independent Samples Test. Hasil perhitungan selengkapnya dapat dilihat pada Tabel 3 berikut.

Tabel 3. Uji Tes “T” Pretes

\begin{tabular}{cccccc}
\hline Kelas & Perbedaan & thitung & Df & t $_{\text {tabel }}$ & Ho \\
\hline VIII B & $9,13>8,91$ & 0,14 & & 2,02 & Diterima \\
VIII C & & & & \\
\hline
\end{tabular}

Dari Tabel 3, dapat diambil keputusan yang dilakukan dengan cara membandingkan nilai $t_{\text {hitung }}$ dengan $t_{\text {tabel. }}$. Nilai thitung $=0,14$ berarti bahwa thitung lebih kecil tabel pada taraf signifikan 5\% maupun taraf signifikan $1 \%$ dengan $\mathrm{df}=\mathrm{N}_{\mathrm{x}}+\mathrm{N}_{\mathrm{y}}-2=23+23-2=44$. Dalam tabel tidak terdapat $\mathrm{df}=44$, maka dari itu digunakan df yang mendekati 44 yaitu $\mathrm{df}=45$. Dengan df diperoleh dari tabel pada taraf sidnifikan 5\% dan 1\% sebesar 2,02 dan 2,69. Ini berarti $t_{\text {hitung }}<t_{\text {tabel }}$, maka diputuskan bahwa $\mathrm{H}_{0}$ diterima dan $\mathrm{H}_{\mathrm{a}}$ ditolak. Dengan demikian dapat disimpulkan bahwa tidak terdapat perbedaan antara kelas VIII B dan VIII C.

\section{Kemampuan Akhir}

Selanjutnya, skor postes diolah dengan menggunakan uji F. Hasil pengujian homogenitas bagi skor postes untuk kelas kontrol dan kelas eksperimen. Selengkapnya dapat dilihat pada hasil rangkuman pada Tabel 4 berikut.

Tabel 4. Uji Homogenitas Postes

\begin{tabular}{cccc}
\hline$F_{\text {hitung }}$ & Df & $F_{\text {tabel }} 5 \%$ & Kriteria \\
\hline 1,763 & 44 & 2,03 & Homogen \\
\hline
\end{tabular}

Dari tabel 4 di atas, maka varians untuk kelas eksperimen dan kelas kontrol yang diperoleh adalah lebih kecil dari taraf signifikan 5\%, dengan $\mathrm{F}_{\text {hitung }}<\mathrm{F}_{\text {tabel }}$ atau 1,763<2,03 maka varians-varians adalah homogen. Kemampuan akhir siswa dilihat berdasarkan skor postes dari kedua kelas penelitian yaitu kelas eksperimen yang mengikuti Pembelajaran Kooperatif tipe CIRC dan kelompok kontrol yang mengikuti pembelajaran konvensional. Selanjutnya skor postes diolah dengan menggunakan chi kuadrat untuk menguji normalitas. Untuk ringkasannya bagi skor postes untuk kelas kontrol dan kelas eksperimen selengkapnya dapat dilihat pada Tabel 5.

Tabel 5. Uji Normalitas Postes

\begin{tabular}{cccc}
\hline Kelas & $\chi_{\text {hitung }}^{2}$ & $\chi_{\text {tabel }}^{2}$ & Kriteria \\
\hline Eksperimen & 7,91 & 14,067 & Normal \\
Kontrol & 4,44 & 18,307 & Normal \\
\hline
\end{tabular}

Berdasarkan hasil penelitian, dapat diamati bahwa nilai $\chi_{\text {hitung }}^{2}$ kelas eksperimen sebesar 7,91 sedangkan untuk nilai $\chi_{\text {hitung }}^{2}$ kelas kontrol sebesar 4,44. Harga $\chi_{\text {tabel }}^{2}$ dalam taraf signifikansi 5\% adalah 14,067 untuk kelas eksperimen dan 18,307 untuk kelas kontrol. Dengan demikian $\boldsymbol{X}_{\text {hitung }}^{2}<\boldsymbol{X}_{\text {tabel }}^{2}$ maka dapat dikatakan bahwa data berasal dari populasi yang berdistribusi normal. Karena telah memenuhi kedua syarat tersebut, barulah analisis data dengan tes "t" dapat dilakukan. Hasil perhitungan selengkapnya dapat lihat pada lampiran L dan kesimpulannya pada Tabel 6 berikut.

Tabel 6. Uji Tes “T” Postes

\begin{tabular}{cccccc}
\hline Kelas & Perbedaan & thitung & df & $t_{\text {tabel }}$ & Ho \\
\hline$\frac{\text { Eksperimen }}{\text { Kontrol }}$ & $83,30>73,96$ & 2,72 & 44 & 2,02 & Ditolak \\
\hline
\end{tabular}

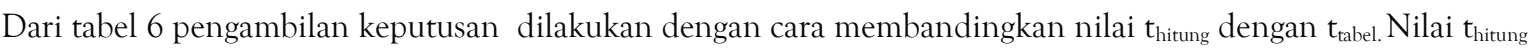
$=2,72$ berarti bahwa $t_{\text {hitung }}$ lebih besar $t_{\text {tabel }}$ baik pada taraf signifikan $5 \%$ maupun taraf signifikan $1 \%$ dengan degrees of freedom $(\mathrm{df})=\mathrm{N}_{\mathrm{x}}+\mathrm{N}_{\mathrm{y}}-2=23+23-2=44$. Dalam tabel tidak terdapat $\mathrm{df}=44$, maka dari itu digunakan $\mathrm{df}$ yang mendekati 44 yaitu $\mathrm{df}=45$. Dengan $\mathrm{df} 45$ diperoleh dari tabel pada taraf signifikan $5 \%$ dan $1 \%$ sebesar 2,02 dan 2,69. Ini berarti thitung $>t_{\text {tabel}}$, maka diputuskan bahwa $\mathrm{H}_{0}$ ditolak dan $\mathrm{H}_{\mathrm{a}}$ diterima yang berarti pemecahan masalah matematika variabel X lebih tinggi dari variabel Y. Dengan demikian, dapat disimpulkan bahwa terdapat perbedaan kemampuan pemecahan masalah antara siswa yang belajar menggunakan model kooperatif tipe CIRC dengan siswa yang memperoleh pembelajaran konvensional. Perbedaan mean kedua variabel juga menunjukan kelas eksperimen dengan pembelajaran kooperatif tipe CIRC lebih baik dari pada kelas konvensional.

\section{Peningkatan Hasil Belajar}

Berdasarkan skor pretes dan postes hasil belajar dapat ditentukan N-Gain untuk mengetahui perbedaan peningkatan hasil belajar siswa. N-Gain dihitung dengan bantuan program microsoft excel dengan membagi selisih skor postes dan skor pretes dengan selisih skor ideal dan skor pretes. Peningkatan hasil belajar siswa dilihat berdasarkan skor N-Gain dari kedua kelas penelitian yaitu kelas eksperimen yang mengikuti pembelajaran model 
kooperatif tipe CIRC dan kelompok kontrol yang pembelajaran secara konvensional. Selanjutnya skor N-Gain diolah dengan menggunakan uji Lilifors. Hasil pengujian normalitas bagi skor N-Gain untuk kelas eksperimen dan kelas kontrol. Selengkapnya dapat dilihat pada hasil rangkuman pada Tabel 7 berikut.

Tabel 7. Uji Normalitas

\begin{tabular}{cccc}
\hline Kelas & $L_{\text {hitung }}$ & $L_{\text {tabel }}$ & Kriteria \\
\hline Eksperimen & 0,1689 & 0,1730 & Normal \\
Kontrol & 0,1604 & 0,1730 & Normal \\
\hline
\end{tabular}

Berdasarkan nilai N-Gain, dapat diamati bahwa nilai $L_{\text {hitung }}$ kelas eksperimen sebesar 0,1689 sedangkan untuk nilai $L_{\text {hitung }}$ kelas kontrol sebesar 0,1604. Harga $L_{\text {tabel }}$ dalam taraf signifikansi $5 \%$ untuk kelas eksperimen adalah 0,1730 dan kelas kontrol 0.1730 . Dengan demikian $L_{\text {hitung }}<L_{\text {tabel }}$ maka dapat dikatakan bahwa data berasal dari populasi yang berdistribusi normal. Selanjutnya skor N-Gain diolah dengan menggunakan uji F. Hasil pengujian homogenitas bagi skor N-Gain untuk kelas eksperimen dan kelas kontrol. Selengkapnya dapat dilihat pada hasil rangkuman pada Tabel 8 berikut.

Tabel 8. Homogenitas N-Gain

\begin{tabular}{cccc}
\hline $\mathrm{F}_{\text {hitung }}$ & $\mathrm{Df}$ & $\mathrm{F}_{\text {tabel }} 5 \%$ & Kriteria \\
\hline 1,907 & 44 & 2,00 & Homogen \\
\hline
\end{tabular}

Dari tabel 8 di atas, maka varians untuk kelas eksperimen dan kelas kontrol yang diperoleh adalah lebih kecil dari taraf signifikan 5\%, dengan $\mathrm{F}_{\text {hitung }}<\mathrm{F}_{\text {tabel }}$ atau 1,907 $<2,00$ maka varians-varians adalah homogen. Karena telah memenuhi kedua syarat tersebut, kemudian dilanjutkan analisis data dengan tes " $t$ " dapat menggunakan uji statistik Compare Mare Independent Samples Test. Hasil perhitungan selengkapnya dapat dilihat pada Tabel 9 berikut.

Tabel 9. Uji Tes " $t$ "

\begin{tabular}{cccccc}
\hline Kelas & Perbedaan & thitung & Df & tabel & Ho \\
\hline $\begin{array}{c}\text { Eksperimen } \\
\text { Kontrol }\end{array}$ & $0,78>0,67$ & 4,07 & 44 & 2,02 & Tolak \\
\hline
\end{tabular}

Dari Tabel 9, dapat diambil keputusan yang dilakukan dengan cara membandingkan nilai thitung $_{\text {dengan }}$ tabel, $_{\text {, nilai }}$ $t_{\text {hitung }}=4,07$ berarti bahwa $t_{\text {hitung }}$ lebih besar $t_{\text {tabel }}$ pada taraf signifikan $5 \%$ maupun taraf signifikan $1 \%$ dengan $\mathrm{df}=$ $\mathrm{N}_{\mathrm{x}}+\mathrm{N}_{\mathrm{y}}-2=23+23-2=44$. Dalam tabel tidak terdapat $\mathrm{df}=44$, maka dari itu digunakan df yang mendekati 44 yaitu $\mathrm{df}=45$. Dengan $\mathrm{df}$ diperoleh dari tabel pada taraf sidnifikan $5 \%$ dan $1 \%$ sebesar 2,02 dan 2,69. Ini berarti $t_{\text {hitung }}>t_{\text {tabel }}$, maka diputuskan bahwa $\mathrm{H}_{0}$ ditolak dan $\mathrm{H}_{a}$ diterima. Dengan demikian, dapat disimpulkan bahwa terdapat peningkatan hasil belajar siswa yang menggunakan model kooperatif tipe CIRC.

\section{PEMBAHASAN}

Berdasarkan hasil penelitian yang diperoleh terlihat bahwa mean hasil postest siswa yang menggunakan Model Pembelajaran kooperatif tipe CIRC lebih tinggi dari pada mean hasil postest siswa yang belajar dengan model pembelajaran konvensional. Dimana mean kelas eksperimen adalah 83,30 dan kelas kontrol 73,96 dan dari analisa data postes dan N-Gain juga menunjukkan perbedaan dimana kelas eksperimen lebih unggul dibandingkankan kelas kontrol. Sebagaimana yang dikatakan Sugiyono (2010), jika kelompok treatment atau kelompok yang diberikan perlakuan lebih baik dari pada kelompok kontrol, maka perlakuan yang diberikan pada kelompok treatment berpengaruh positif. Dengan demikian, hasil analisa ini mendukung rumusan masalah yang diajukan yaitu terdapat perbedaan dan peningkatan kemampuan pemecahan masalah matematika antara siswa yang belajar menggunakan Model pembelajaran Kooperatif tipe CIRC dengan siswa yang memperoleh pembelajaran konvensional.

Dilihat dari ketuntasan klasikal antara kelas eksperimen dengan kelas kontol juga terlihat perbedaan dimana untuk kelas eksperimen ketuntasan klasikalnya mencapai $91 \%$ sedangkan untuk kelas kontrol hanya $51 \%$, ini menjelaskan bahwa kemampuan pemecahan masalah matematika dengan menggunakan model pembelajaran kooperatif tipe CIRC lebih baik dari pembelajaran konvensional. Hal ini dimungkinkan karena pembelajaran telah berubah dari paradigma pembelajaran yang berpusat pada guru kepada pembelajaran yang menekankan pada keaktifan siswa dalam berpikir setelah proses membaca, selanjutnya berbicara dan membagi ide dengan temannya, kemudian menuliskan hasil diskusi. Dengan terjadinya interaksi antara siswa seperti yang dijabarkan diatas akan diperoleh banyak keuntungan, antara lain diskusi dan berbagi pengetahuan dan pendapat, refleksi atas hasil pemikiran masing-masing, dan akhirnya akan bermuara pada peningkatan pemahaman dan pemecahan masalah untuk masing-masing anggota kelompok. 


\section{SIMPULAN DAN SARAN}

\section{Simpulan}

Berdasarkan hasil penelitian, dapat diambil kesimpulan sebagai berikut: 1) terdapat perbedaan kemampuan pemecahan masalah dari penerapan pembelajaran kooperatif tipe CIRC siswa kelas VIII SMP Negeri 2 Bengkalis; dan 2) terdapat perbedaan peningkatan hasil belajar siswa yang menggunakan model kooperatif tipe CIRC dengan pembelajaran konvensional yaitu dengan nilai N-Gain untuk kelas eksperimen 0,78 adalah kriteria tinggi dan kelas kontrol 0,68 adalah kriteria sedang.

\section{Saran}

Berdasarkan hasil penelitian ini, peneliti memberikan saran atas beberapa kendala yang dihadapi peneliti selama penelitian, adapun kendala-kendala dan saran, yaitu: 1) kurangnya kerjasama siswa dalam belajar apabalagi belajar secara kelompok maka menyebabkan kurang maksimal penerapan CIRC, maka peneliti menyarankan untuk menerapkan CIRC sebaiknya membangun motivasi siswa untuk belajar agar lebih dapat bekerjasama dalam proses belajar mengajar agar mendapatkan hasil lebih maksimal; 2) kurang matangnya dalam membuat skenario pembelajaran kooperatif tipe CIRC sehingga proses pembelajaran kurang maksimal, maka peneliti menyarankan supaya bagi yang ingin menggunakan pembelajaran kooperatif tipe CIRC untuk membuat skenario pembelajaran kooperatif tipe CIRC dengan lebih matang baik instrumen berupa RPP, LKS dll yang dibutuhkan dalam proses pembelajaran; dan 3) bahasan matematika yang dikembangkan dalam penelitian ini hanya terdiri dari satu kompetensi dasar. Masih terbuka peluang bagi peneliti lain untuk bereksperimen pada standar kompetensi yang lain atau sekolah lain.

\section{DAFTAR RUJUKAN}

Hartono. 2008. Statistik Untuk Penelitian.Yogyakarta: Pustaka Pelajar.

Isjoni. 2009. Pembelajaran kooperatif Meningkatkan Kecerdasan Komunikasi Antar Peserta Didik.Yogyakarta: Pustaka Pelajar.

Mulyono Abdurrahman. 2003. Pendidikan Bagi Anak Kesulitan Belajar. cet.II; Jakarta: PT. Rineka Cipta.

Punaji Setyosari.2010. Metode Penelitian Pendidikan. Jakarta: Kencana.

Slavin, Robert E.2005. Cooperative Learning, diterjemahkan oleh NarulitaYusron dengan judul Cooperative Learning. Bandung: Nusa Media.

Sugiyono.2010. Metode Penelitian Pendidikan Kuantitatif Kualitatif dan R \& D. Bandung: Alfabeta.

Wallec, John A. Van De. 2006. Elementary and Middle School Mathematics, diterjemahkan oleh Suyono dengan judul: Matematika Sekolah Dasar dan Menengah Pengembangan Pengajaran. Cet.VI; Jakarta: Erlangga. 